\title{
HISTOLOGICAL STUDY ON TUBERISATION OF POTATO (SOLANUM TUBEROSUM L.) PROMOTED BY INHIBITORS OF GIBBERELLIN BIOSYNTHESIS
}

\author{
EWA KuPIDŁOWSKa, MaŁgORZATA BANAŚ \\ Department of Plant Anatomy and Cytology, Warsaw University \\ ul. Krakowskie Przedmieście 26/28, 00-927 Warsaw, Poland
}

(Received: July 1, 1991. Accepted: December 1, 1993)

\begin{abstract}
The application of antigibberellins to potato plant cultures results in an accelerated tuber appearance, caused by stimulation of pith-,and cortex-cell growth, particularly in the radial direction. Their growth considerably precedes the initiation of parenchymatous cell divisions, which are the first steps of naturally occurrring tuberisation, regulated by a different mechanism than the quantitative proportion of endogenous gibberellins and cytokinins. Part of the cortex cells change the orientation of their divisions to a periclinal one. The xylem parenchyma cells also undergo hypertrophy.
\end{abstract}

KEY WORDS: Solanum tuberosum, potato, tuberisation, growth retardants, antigibberellins.

\section{INTRODUCTION}

Tuberisation is a process consisting of anatomical and morphological changes of the stolon, transforming it into a storage organ. Tuberisation is preceded by inhibition of stolon elongation. The volumetric growth of the subapical internodes is based upon increased cell number arising from divisions of parenchyma cells in the cortex, pith and perimedulla. These tissues are nonmeristematic and cell division is regulated here differently from that of cambium.

The results obtained previously indicate that inhibition of growth in lenght and succeeding tuberisation are accompanied by a decrease in endogenous gibberellins (Okazawa 1960, Racca and Tizio 1968, Lezica 1970).

Enhanced tuberisation has been observed in plants treated with growth inhibitors such as CCC, coumarin and phenol acids (Smith and Rappaport 1969, Ewing 1981) and CCC is used to induce tuberisation in in vitro cultures (Estrada et al. 1986). These experiments, however, were not accompanied by histological observations of tuberisation caused by inhibition of gibberellin production or, possibly, action.

The present study was undertaken to investigate whether the tuberisation stimulated by antigibberellins was affected also at tissue level.

\section{MATERIALS AND METHODS}

Plant material - In order to presprout, tuber fragments of potato, (Solanum tuberosum L., cv Iris) each with one eye, were placed in moist sand at approximately $15^{\circ} \mathrm{C}$.

Sprouts with a developed root system were separated from the mother tubers and transferred to containers filled with a mixture of sand and compost soil. The experiment was carried out in May-June and plants were grown in a greenhouse at day/night temperatures $20^{\circ} / 15^{\circ} \mathrm{C}$ under natural lighting.
Chemicals - The following growth retardants believed to inhibit the synthesis of endogenous gibberellins (Rademacher et al. 1987) were used in the experiment:

(2-chloroethyl) trimethylammonium chloride, CCC (VEB Chemia DDR): succinic acid 2, 2 dimethyl-hydrazide, SADH (Uniroyal, USA); (2Rs, 3Rs)-1-(4-chlorophenyl)-4, 4-dimethyl-2-(1, 2, 4-triazol-1-y1) pentan-3-ol, paclobutrazol (ICI, Plant protection Division, Bracknell, UK).

Each antigibberellin was dissolved in water to a final concentration of active ingredient of $100 \mathrm{mg}^{-1}$ and applied to the soil.

Treatments - The experiment was started after the first stolons had formed. The plant material was divided into three experimental groups and control, each with 12 plants. Each plant was treated daily with $100 \mathrm{ml}$ solution of antigibberellin or water respectively. The material was collected after $3,5,7$, 10 days, samples of control plants were additionally taken after $14,18,22,25$ days since these plants had then begun tuberisation. Stolons and tubers were removed from them, fixed in chrom-aceto-formalin (CrAF), dehydrated in a series of alcohols and xylene and embedded in paraffin wax. Sections $7-$ $10 \mu \mathrm{m}$ thick were cut on a Reichert-Rotocut microtome and stained with Ehrlich's haematoxylin and fuchsin 0 with light green before examination by light microscopy using an Amplival (Carl Zeiss-Jena) microscope.

\section{RESULTS}

Histogenesis of the control tubers - A typical internal structure of the stolon before tuberisation is presented in Fig. 1A. The stolon was covered by a single layer of epidermis. The cortex underneath the epidermis was composed of several morphologically distinct layers.

The hypodermis immediately beneath the epidermis was composed of closely adhering, radially elongated cells. Be- 

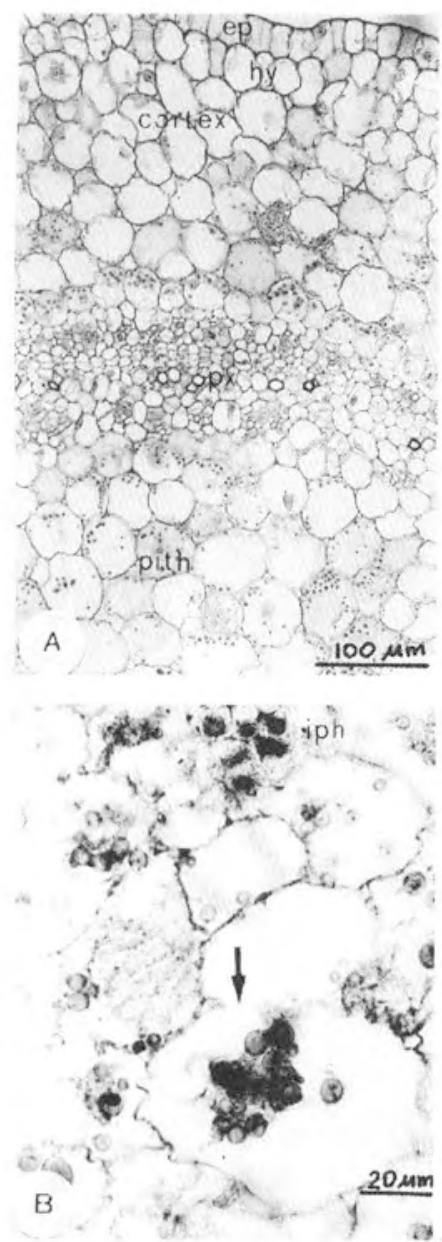
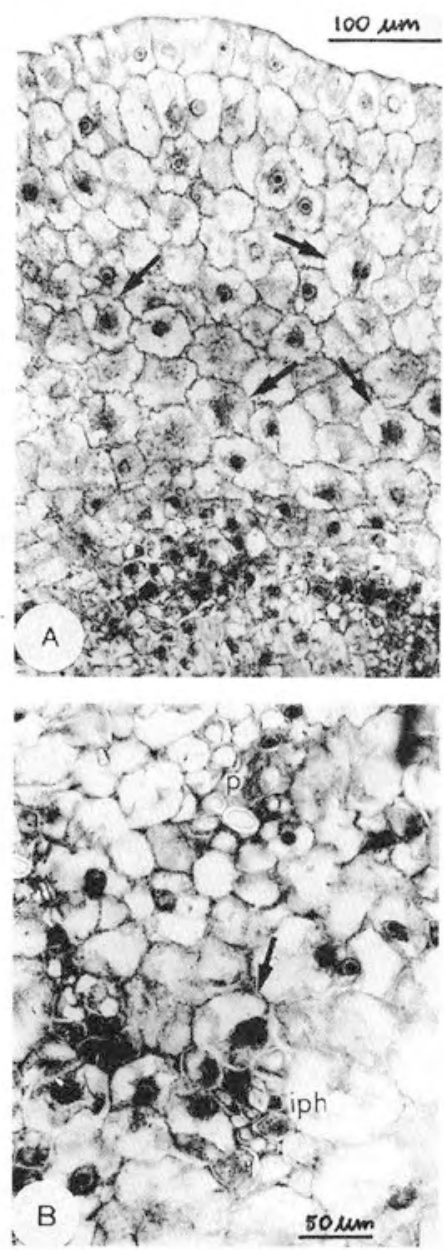
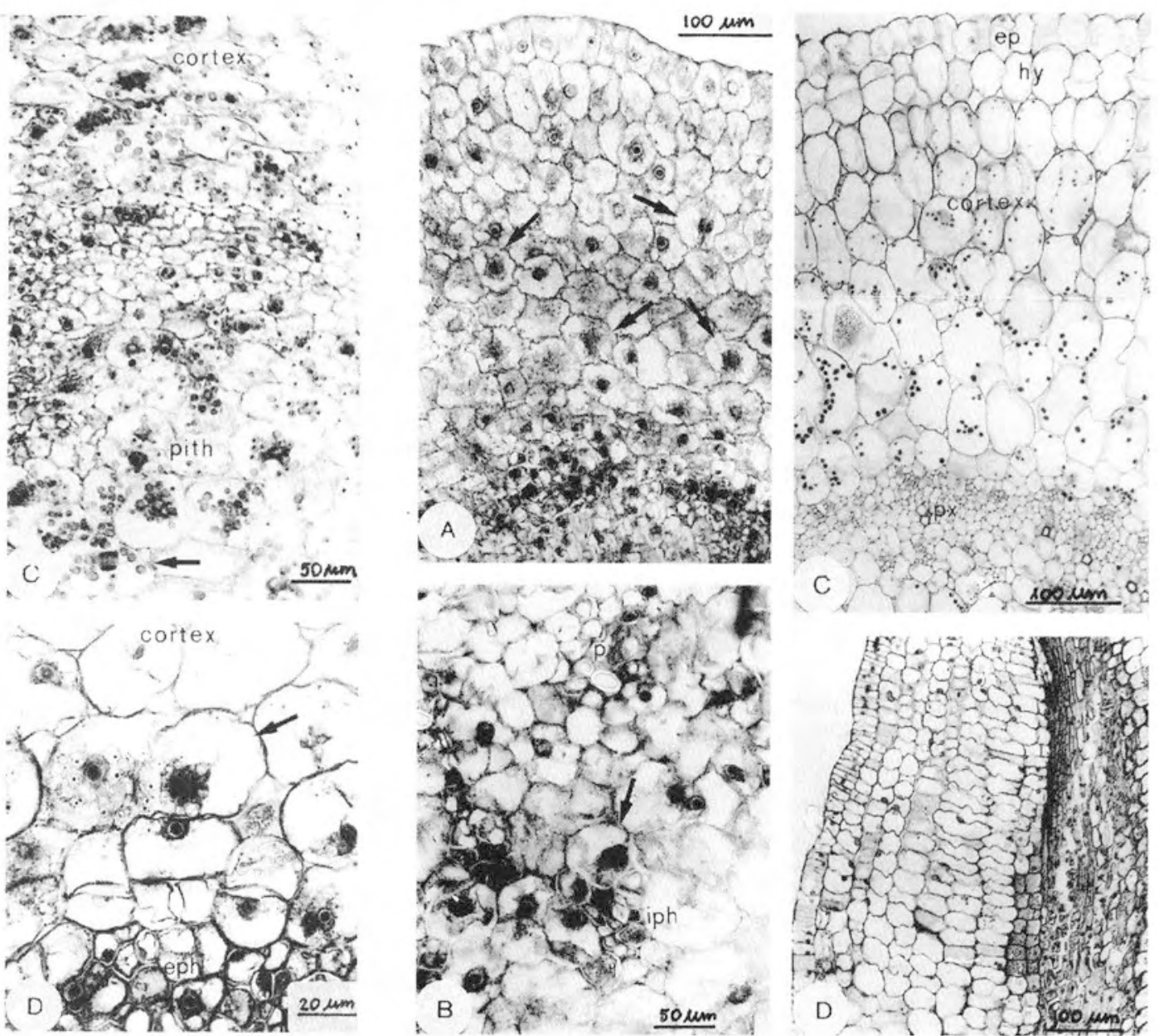

Fig. 1. Transverse section of untreated stolons stained with Ehrlich's haematoxylin.

A - primary structure of stolon, $x 160$.

B - telophase in parenchymatous cell of pith (arrow), x 500 .

C - telophase in pith cell (arrow), $x 200$.

D - telophase in cortex cell (arrow), x 500. ep - epidermis, hy - hypodermis, $\mathrm{px}$ - primary xylem, iph - internal phloem, eph - external phloem

neath this, the typical parenchyma consisted of several layers of isodiametric cells and was differentiated into two zones. Cells lying under the hypodermis contained numerous small vacuoles and were smaller, more closely arranged than those deeper in the stolon where the cells were larger, loosely arranged and had larger vacuoles. The endodermis was seen clearly only in the early stages of stolon development. The vascular system was composed of bicollateral vascular bundles. A layer of undifferentiated cells (the so-called perimedullary zone) remained between the internal phloem and protoxylem. The central part of stolon was occupied by the parenchymatous pith.

The first stage of tuberisation involves anisotropic divisions of pith cells. The first divisions were seen during the differentiation of primary vascular tissues. Cell divisions and growth were responsible for the increased pith volume (Fig. 1B, C) Divisions were subsquently resumed in the cortex. The parenchymatous cells divided anticlinally. This led to an increase of the cortex surface, whereas the number of cell layers remained unchanged (Figs. 1D, 2A). The role of the cortex in the thickening of the stolons was limited and consisted mainly in the growth of cells.

The next stage of tuberisation included the division of perimedullary zone cells (Fig. 2B). The undifferentiated cells

Fig. 2. Transverse section of untreated, thickened stolons stained with Ehrlich's haematoxylin.

A - cortex, arrow indicates anticlinal divisions of the cells, x 160 .

B - perimedullary zone, arrow indicates posttelophase in parenchymatous cell, $x 200$.

$\mathrm{C}$ - transverse section of thickened stolon treated with SADH, stained with fuchsin 0 and light green. Cortex cells abnormally expanded in radial direction, $\mathrm{x} 160$.

D - longitudinal section of thickened stolon treated with paclobutrazol, stained with fuchsin 0 and light green. Radially enlarged cells of the cortex, x 120. ep epidermis, hy - hypodermis, px - primary xylem, iph - internal phloem

found between the protoxylem and internal phloem divided and their derivatives grew and differentiated into cells of the storage parenchyma. This resulted in the separation of internal phloem groups and their withdrawal to the far inside of the stolon.

Histogenesis of tubers after application of antigibberellin The response of plants to treatment with growth retardants was indentical in the three experimental groups and independent of the type of growth retardant applied.

The first observable response was an increase in size of the parenchymatous cells of the cortex and pith. These cell layers grew intesively before active divisions were resumed. Their width considerably exceeded that of analogous cells of the control stolons at an identical developmental stage (Fig. 2C).

The analysis of longitudinal sections of the tuberising stolons showed that the direction of the cortex and pith cell growth was changed by the antigibberellins. In control stolons cells expanded isodiametrically, while radial growth prevailed in stolons treated with antigibberellins (Figs. 2D, 3A, B). The first divisions of the cortex cells were periclinal, causing an increase in the number of cell rows across the cortex (Fig. 3C). 

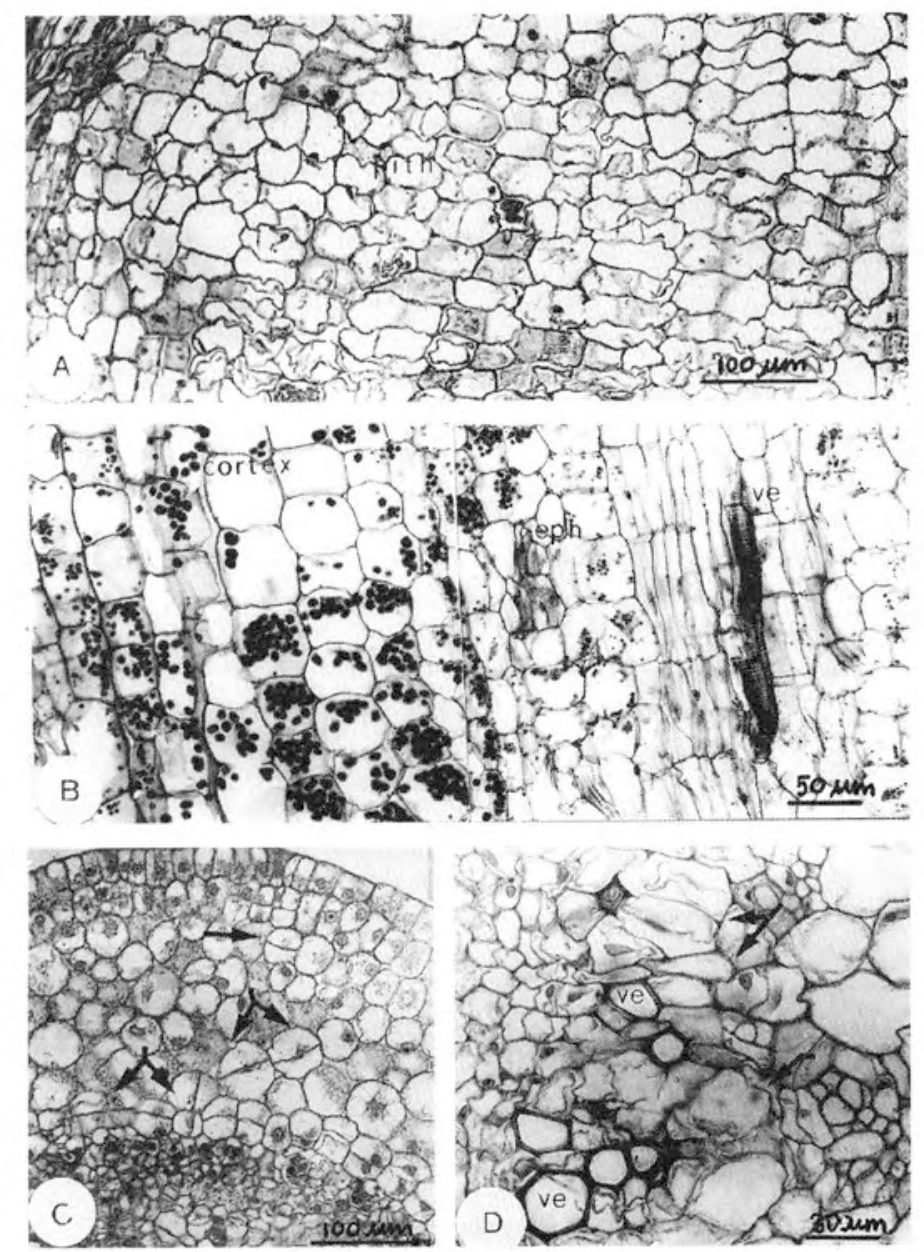

Fig. 3.

A - longitudinal section of thickened stolon treated with paclobutrazol, stained with fuchsin 0 and light green. Parenchymatous cells of pith, enlarged in radial direction, $\times 160$.

B - longitudinal section of untreated thickened stolon stained with fuchsin 0 and light green. Isodiametric cells of cortex, x 200.

C - transverse section of stolon treated with paclobutrazol, stained with Ehrlich's haematoxylin. Arrow indicates sister cells just after periclinal division, $\mathrm{x} 150$

D - transverse section of stolon treated with paclobutrazol, stained with fuch$\sin 0$ and light green. Hypertrophy of parenchymatous cells of primary xylem, x 300. ve - vessel, eph - external phloem

The application of antigibberellins resulted also in hypertrophy of the xylem parenchyma cells, a tissue which does not participate in tuberisation (Fig. 3D).

Figure 4 illustrates the effect of antigibberellins on cell size. Since synchronous growth of stolons cannot be obtained in greenhouse cultures, the mean cortex cell diameters were calculated after dividing the material into seven groups of increasing cortical width. It is evident from the data that cortical cells grew to a larger diameter in the presence of growth retardants.

\section{DISCUSSION}

The first response of stolons to the inhibitors of gibberellin synthesis was the hypertrophy of parenchyma cells. Similar effects were obtained when antigibberellins acted on pea-plant roots and lettuce cotyledons (Tanimoto 1987, Vazquez et al. 1988). The observed radial cell growth can be ascribed to the disorientation of the peripheral microtubules, determining the spatial organization of cellulose microfibrils and to changes in
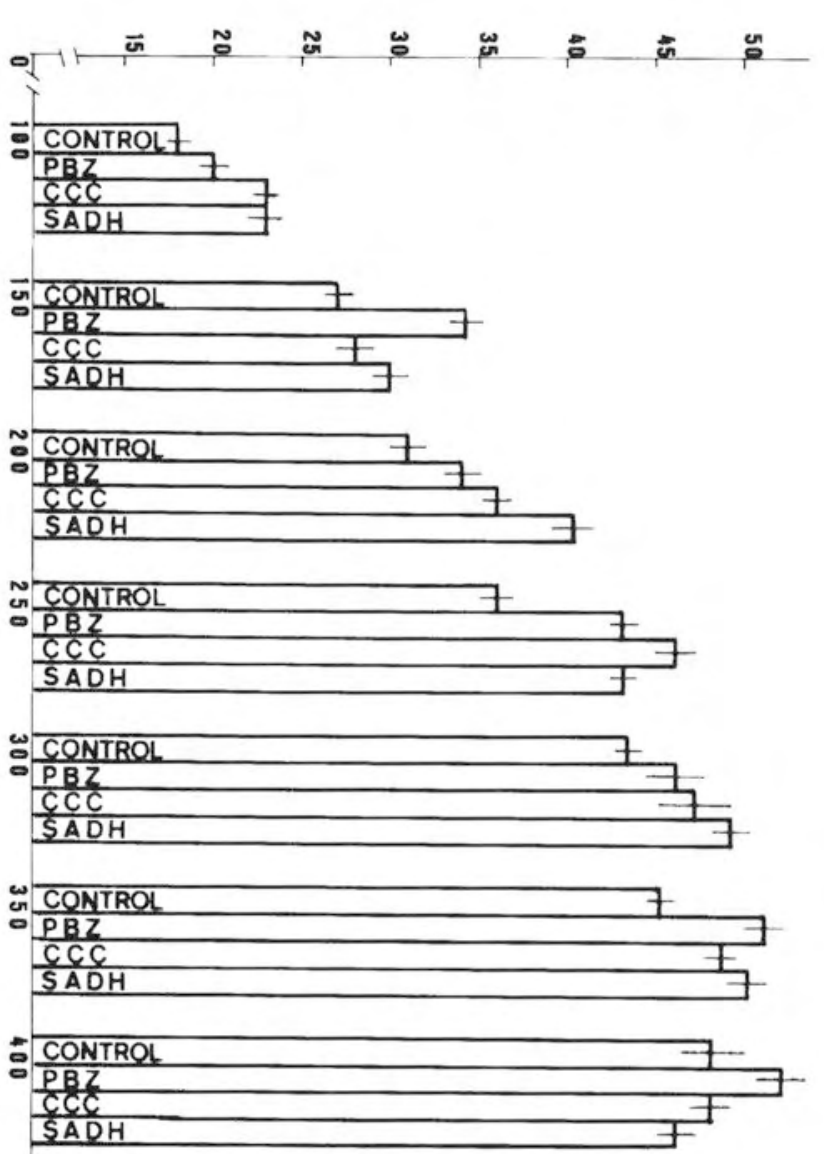

Fig. 4. Diameter of cortex cell at different stages of stolon growth. The vertical bars indicate the mean standart error. CCC - $(2$ chloroethyl) trimethylammonium chloride, $\mathrm{PBZ}$ - paclobutrazol, SADH - succinic acid 2,2 dimethyl - hydrazide

the sugar content in cell walls (Shibaoka 1974, Nishitani and Matsuda 1982, Tanimoto 1988). Changes in the microtubule system caused by the lack or inactivation of endogenous gibberellins are indicated by the change of the direction of the cortex-cell growth and divisions.

The earlier appearance of tubers observed after treating with antigibberellins consisted mainly in stimulating cell growth which precedes cortex and pith-cell divisions. However, the fundamental mechanism of tuberisation, consisting in divisions of cortex, pith and perimedulla cells is not considerably modified after application of antigibberellins. The decrease in the level of endogenous gibberellins does not seem to directly induce tuberisation. However, it has an effect on secondary processes, such as the direction of cell division and intensity of cell growth, probably due to changes in the spatial and chemical cell-wall structure.

The results of the present study are not in accordance with the view (Railton and Wareing 1973, Mauk and Langille 1978) that shifting the balance between gibberellins and cytokinins in favour of cytokinins is responsible for tuberisation. The initiation of the division of nonmeristematic tissues, which is the essence of tuberisation, is probably subjected to a different control mechanism than the quantitative proportion of gibberellins and cytokinins. 


\section{LITERATURE CITED}

ESTRADA R., TOVAR P., DODDS J., 1986. Induction of in vitro tubers in a broad range of potato genotypes. Plant Cell., Tissue and Organ Culture 7: 3-10.

EWING E.E., 1981. Heat stress and tuberization stimulus. Amer. Potato J.58: $31-49$.

LEZICA R.F.P., 1970. Formation of gibberellin-like substances on potato plants during tuberization in relation to daylength and temperature. Potato Res. 13: 323-331.

MAUK C.S., LANGILLE A.R., 1978. Physiology of tuberization in Solanum tuberosum. Cis-zeatin riboside in the potato plants, its identification and changes in the endogenous levels as influenced by temperature and photoperiod. Plant Physiol. 62: 438-442.

NISHITANI K., MATSUDA Y., 1982. Roles of auxin and gibberellic acid in growth and maturation of epicotyls of Vigna angularis: cell wall changes. Physiol. Plant. 56: 38-45.

OKAZAWA Y., 1960. Studies on the relation between tuber formation of potato and its natural gibberellin content. Proc. Crop. Sci. Soc. Japan 29: 121-124.

RACCA R.W., TIZIO R., 1968. A preliminary study of changes in the content of gibberellin-like substances in the potato-D plant in relation to the tuberisation mechanism. Europ. Potato J. 11: 213-220.
RADEMACHER W., FRITSCH H., GRAEBE J.E., SAUTER H., JUNG J., 1987. Tetcyclasis and triazole-type plant growth retardants: their influence on the biosynthesis of gibberellins and other metabolic processes. Pesticides Sci. 21: 241-252.

RAILTON I.D., WAREING P.F., 1973. Effect of daylength on endogenous gibberellins in leaves of Solanum andigena. Changes in levels of acidic gibberellin-like substances. Physiol. Plant. 28: 88-94.

SHIBAOKA H., 1974. Involvement of wall microtubules in gibberellin promotion and kinetin inhibition of stem elongation. Plant Cell Physiol. 15: 255-263.

SMITH O.E., RAPPAPORT L., 1969. Gibberellins, inhibitors and tuber formation in the potato, Solanum tuberosum. Amer. Potato J. 6: 185-191.

TANIMOTO E., 1987. Gibberellin-dependent root elongation in Lactuca sativa: recovery from growth retardant-supressed elongation with thickening by low concentration of $\mathrm{GA}_{3}$. Plant Cell Physiol. 27: 963 973.

TANIMOTO E., 1988. Gibberellin regulation of root growth with change in galactose content of cell walls in Pisum sativum. Plant Cell Physiol. 29: 269-280.

VAZQUEZ M.D., BARCELO J., CASTELLANO B., GONZALES E., 1988. Effect of (2-Chloroethyl)-trimethyl-amonium chloride (CCC) on structure and ultrastructure of Lactuca sativa cotyledons. Photosynthetica $22: 76-82$.

\section{ANALIZA HISTOLOGICZNA TUBERYZACJI ZIEMNIAKA (SOLANUM TUBEROSUM L.) STYMULOWANEJ INHIBITORAMI BIOSYNTEZY GIBERELIN}

\section{STRESZCZENIE}

Traktowanie roślin ziemniaka antygiberelinami powoduje przyspieszone formowanie bulw. Analiza histologiczna pozwala stwierdzić, że w początkowym stadium jest ono spowodowane stymulacją wzrostu komórek kory i rdzenia w kierunku radialnym. Hypertrofii ulegają także komórki miękiszu drzewnego. Wzrost ten znacznie wyprzedza inicjację podziałów komórek kory, strefy okołordzeniowej i rdzenia, które są podstawowym mechanizmem tuberyzcji w warunkach naturalnych, a które zachodzą także w roślinach traktowanych antygiberelinami. Podziały te podlegają prawdopodobnie innemu czynnikowi regulacji niż ilościowa równowaga endogennych giberelin i cytokinin. 